\section{Expression of SPANX proteins in normal prostatic tissue and in prostate cancer}

\author{
M. Salemi, ${ }^{2}$ A.E. Calogero, \\ G. Zaccarello, ${ }^{2,5}$ R. Castiglione, ${ }^{1,4}$ \\ A. Cosentino, ${ }^{3}$ M. Catanuso, ${ }^{1}$ E. Vicari, \\ G. Rappazzo ${ }^{2}$
}

'Section of Endocrinology, Andrology and Internal Medicine, Department of Biomedical Sciences, and Master in Andrological and Human Reproduction Sciences, University of Catania, Catania, Italy; 2Department of Animal Biology, University of Catania, Catania, Italy; ${ }^{3}$ Unit of Pathology, Gravina Hospital, Caltagirone (CT), Italy; ${ }^{4}$ Section of Clinical Pathology and Molecular Oncology, Department of Biomedical Sciences, University of Catania, Catania, Italy; ${ }^{5}$ Laboratory of Immunogenetics, Department of Genetics, Biology and Biochemistry, University of Torino Medical School, Torino, Italy

\section{Abstract}

The sperm protein associated with the nucleus in the $\mathrm{X}$ chromosome (SPANX) gene family encodes for proteins that are not only expressed in germ cells, but also in a number of tumors. In addition, SPANX genes map in an interval of the X chromosome (namely, Xq27), which has been found to be associated with familial prostate cancer by linkage analysis. The aim of this study was therefore to evaluate $S P A N X$ protein expression in normal prostate tissues and in prostate carcinoma. For this purpose, formalin-fixed and paraffin-embedded sections obtained from 15 normal (at autopsy) donors and 12 men with prostate cancer were analyzed by immunohistochemistry. About $40 \%$ of both normal and tumor prostate samples resulted SPANX positive. Signals were exclusively within the nucleus in normal prostate cells, whereas both nuclear and cytoplasmic positivity was observed in tumor cells. In conclusion, these findings showed that SPANX genes are expressed in both normal and tumor prostate gland, but the latter showed a peculiar cytoplasmic staining positivity. This suggests a possible association between SPANX over expression and prostate cancer development. Additional studies are needed to corroborate this hypothesis.

\section{Introduction}

Prostate cancer, one of the most commonly diagnosed male malignancies in Western countries, is now the leading cause of cancer-related death in men. ${ }^{1}$ Over the years, genetic epidemiological evidence has accumulated in favor of a considerable hereditary component in prostate cancer susceptibility. Genetic linkage analysis in 360 hereditary prostate cancer pedigrees revealed the presence of a hereditary prostate cancer susceptibility gene(s) at Xq2728 (HPCX). ${ }^{2}$ In agreement with this finding, further data were obtained by analyzing linkage disequilibrium of molecular markers of $X$ chromosome in a Finnish $\mathrm{X}$ haplotype. ${ }^{3} \mathrm{Xq} 27$ is a region containing a number of genes important in cancer and embryonic development, including the sperm protein associated with the nucleus in the X chromosome (SPANX) gene family ${ }^{4,5}$ that consists of the two subfamilies $S P A N X-N$ and SPANX-A/D (Human genome build 37.1). SPANX-A/D genes map within segmental duplications, ${ }^{6,7}$ which are regions involved in genomic rearrangements resulting in an abnormally high level of structural polymorphisms. ${ }^{8}$ Accordingly, the SPANX-B and the $S P A N X-C$ genes were shown to be present in a variable number of copies (ranging from one to $>11$ ) in the normal population; ${ }^{4,7}$ however, no association was found between SPANX copy number and the occurrence of hereditary prostate cancer by the genetic locus described by $\mathrm{Xu}_{,}{ }^{2}$ thus leaving uncertain the possible identification of the aforementioned locus with SPANX gene cluster.

SPANX proteins are normally expressed in germ cells; ${ }^{4,10}$ however, their expression has also been detected in a number of tumors, including melanoma, myeloma, glyoblastoma, breast carcinoma, prostate cancer, and testicular germ cell tumors. ${ }^{5,11-14}$ The present study was undertaken to evaluate the expression of SPANX proteins in normal prostate tissues and in prostate cancer by immunohistochemistry.

\section{Materials and Methods}

\section{Patients}

The analysis was carried out on 15 normal (at autopsy) donors and 12 men with prostate cancer following radical prostatectomy. Patients (71.7 \pm 1.8 years) and normal controls $(74.5 \pm 1.3$ years) had a similar mean age (Table 1). Patients' histological diagnosis, Gleason scores and pre-surgery serum PSA levels are shown in Table 1.

The protocol was approved by the internal Institutional Review Board and an informed
Correspondence: Michele Salemi, Sezione di Endocrinologia, Andrologia e Medicina Interna, Dipartimento di Scienze Biomediche, Università di Catania, Policlinico "G. Rodolico", via S. Sofia 78, Edificio 4, Stanza 2C19, 95123 Catania, Italy. E-mail: micezia@tiscali.it

Key words: cancer, prostate, immunohistochemistry, SPANX gene.

Received for publication: 2 June 2010. Accepted for publication: 8 August 2010.

This work is licensed under a Creative Commons Attribution 3.0 License (by-nc 3.0).

(C) Copyright M. Salemi, et al., 2010 Licensee PAGEPress, Italy

European Journal of Histochemistry 2010; $54: e 41$ doi:10.4081/ejh.2010.e41

written consent was obtained from each patient with prostate cancer or, if deceased, by his relatives.

\section{Immunohistochemical staining}

Four $\mu \mathrm{m}$ formalin-fixed and paraffinembedded prostate sections were processed following the standard protocol previously described. ${ }^{5}$ We did not observe any time-related effect on immunostaining with the antibody used for this study nor with any other antibody used for diagnosis. A polyclonal serum against the common SPANX epitope TPTGDSDPQP, developed in mouse, was used, as reported in a previous study. ${ }^{4}$ As negative control, antiSPANX serum was pre-incubated with the immunizing peptide (100 ng) for $1 \mathrm{~h}$. Tissues were visually scored at $20 \mathrm{X}$ magnification for SPANX positivity; the fraction of SPANX-positive cells was evaluated independently in a blinded fashion by two of us in microscopic fields where non prostatic cells (infiltrating leukocytes, fibroblasts, etc.) were as few as possible. Since no significant difference was observed between the two observers, a mean value was used.

\section{Statistical analysis}

Results were expressed as mean \pm SEM. Comparisons between the percentages of SPANX-positive cells were carried out by the Student's t test (SPSS 9.0 software package for Windows). $\mathrm{P}<0.05$ were considered statistically significant.

\section{Results}

Normal tissues showed only a SPANX-positive nuclear signal in 6 samples out of the 15 examined (40\%), with a mean of $21.7 \pm 7.2 \%$ 
cells with SPANX-positive nuclei (Figure $1 \mathrm{~A}$, C; Table 1). The expression of SPANX was also evaluated in 12 samples of prostate carcinoma with a mean Gleason score of $3.5 \pm 0.2$ and $3.2 \pm 0.2$ and a grading ranging from G1 to G3. Five samples exhibited a SPANX-positive nuclear signal (41.7\%) with a mean of $32.9 \pm 11.8 \%$ positive nuclei (Figure $1 \mathrm{~B}, \mathrm{D}$; Table 1). Moreover, cytoplasmic staining for SPANX was observed in the $27.5 \pm 9.9 \%$ of the cells (range: 60-75). None of the controls, analyzed in parallel, exhibited cytoplasmic staining $(\mathrm{P}<0.001$ vs. prostate carcinoma samples). No cytoplasmic staining was observed in the absence of nuclear staining in prostate cancer tissue (Table 1).

\section{Discussion}

This is the first demonstration that SPANX genes are expressed in a normal somatic tissue, apart the already known expression in germ cells. ${ }^{4,5}$ The percentage of cells showing a SPANX-positive nuclear staining was comparable both in normal and in pathologic tissues; prostate cancer cells showed also a cytoplasmic staining. This peculiar feature of SPANX staining, if confirmed by larger cohort studies, may be of clinical usefulness for the immunohistochemical differential diagnosis of prostate carcinoma. Cytoplasmic SPANX labeling is a common finding in malignant cancer cells, such as embryonal carcinomas ${ }^{5}$ and melanomas. ${ }^{15,16}$ In addition, evidences of cytoplasmic labeling in melanomas has been shown by Westbrook $e t$ $a l .{ }^{17}$ On the basis of extensive observations of histological samples, we believe that the cytoplasmic signal represents a leakage of SPANX proteins from the nucleus. A definitive answer
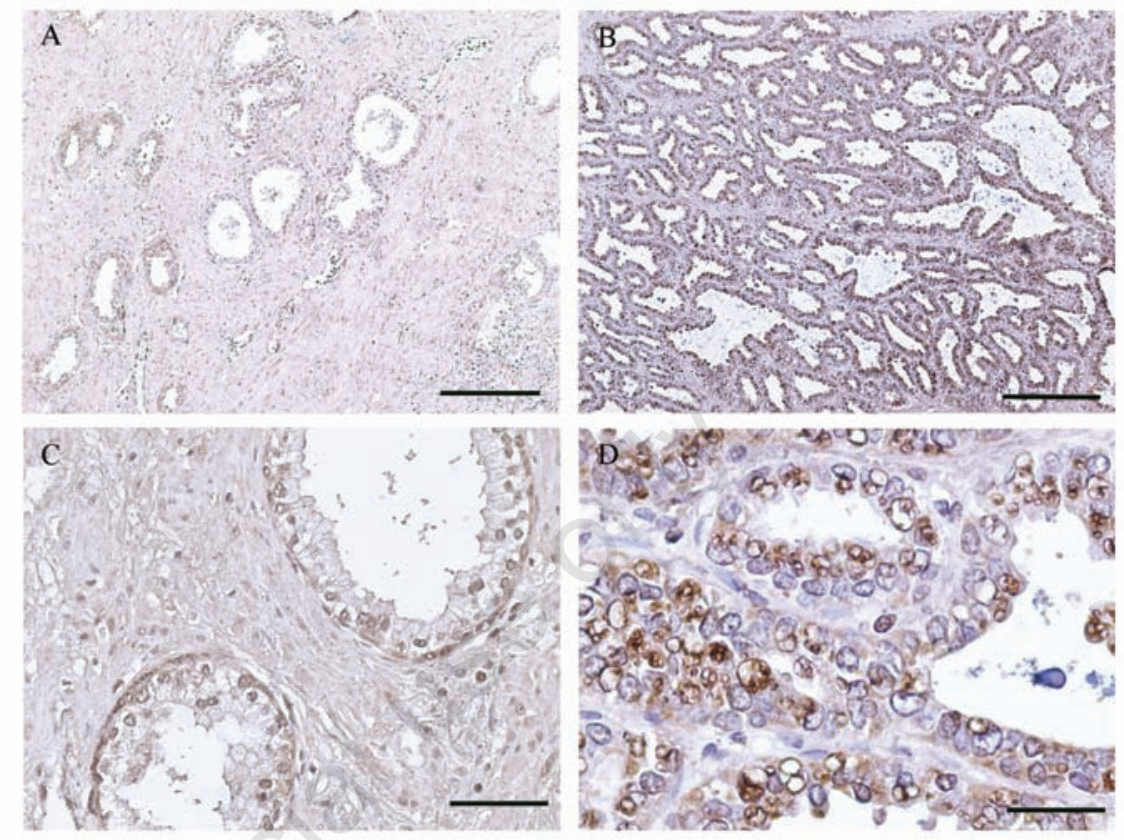

Figure 1. Immunohistochemistry of prostate. (A) Normal prostatic tissue; (B) prostate carcinoma (A, B Hematoxylin counterstain; bar $=800 \mu \mathrm{m})$; $(\mathrm{C})$ normal prostatic tissue (Hematoxylin counterstain; bar $=200 \mu \mathrm{m})$; (D) prostate carcinoma (Hematoxylin counterstain; bar $=80 \mu \mathrm{m})$.

Table 1. Characteristics of healthy prostate tissue donors and of patients who underwent radical prostatectomy for prostate carcinoma.

\begin{tabular}{|c|c|c|c|c|c|c|c|c|c|c|c|c|}
\hline \multicolumn{4}{|c|}{ Normal prostate (autopsy) } & \multicolumn{9}{|c|}{ Prostate carcinoma (radical prostatectomy) } \\
\hline ID & $\begin{array}{l}\text { Age } \\
\text { (years) }\end{array}$ & $\begin{array}{c}\text { Positive } \\
\text { cell } \\
\text { nuclei (\%) }\end{array}$ & $\begin{array}{l}\text { Positive cell } \\
\text { cytoplasm (\%) }\end{array}$ & ID & $\begin{array}{c}\text { Age } \\
\text { (years) }\end{array}$ & $\begin{array}{c}\text { PSA } \\
(\mathrm{ng} / \mathrm{mL})\end{array}$ & pT & $\mathrm{N}$ & $\begin{array}{l}\text { Gleason } \\
\text { score }\end{array}$ & $\mathrm{G}$ & $\begin{array}{c}\text { Positive } \\
\text { cell } \\
\text { nuclei (\%) }\end{array}$ & $\begin{array}{c}\text { Positive cell } \\
\text { cytoplasm (\%) }\end{array}$ \\
\hline 0.1 & 63 & 0 & 0 & 1 & 72 & 7.8 & pT3 & 0 & $4+3$ & $\mathrm{G} 2$ & 80 & 70 \\
\hline 0.2 & 77 & 0 & 0 & 2 & 63 & 9.2 & pT3 & 0 & $4+4$ & G3 & 0 & 0 \\
\hline 0.3 & 72 & 55 & 0 & 3 & 79 & 8.7 & pT3 & $\mathrm{NA}$ & $4+4$ & G3 & 0 & 0 \\
\hline 0.4 & 71 & 60 & 0 & 4 & 70 & 7.6 & pT3 & 0 & $3+3$ & $\mathrm{G} 2$ & 75 & 65 \\
\hline 0.5 & 68 & 0 & 0 & 5 & 72 & 11.6 & pT3 & NA & $4+3$ & $\mathrm{G} 2$ & 80 & 60 \\
\hline 0.6 & 80 & 0 & 0 & 6 & 79 & 6.8 & pT2b & NA & $3+3$ & G2 & 0 & 0 \\
\hline 0.7 & 79 & 55 & 0 & 7 & 72 & 8.2 & pT3 & 0 & $3+2$ & G1 & 75 & 60 \\
\hline 0.8 & 77 & 0 & 0 & 8 & 77 & 9.6 & pT2b & 0 & $3+4$ & $\mathrm{G} 2$ & 0 & 0 \\
\hline 0.9 & 76 & 50 & 0 & 9 & 74 & 10.1 & pT3 & NA & $4+4$ & $\mathrm{G} 2$ & 0 & 0 \\
\hline 0.10 & 80 & 0 & 0 & 10 & 73 & 9.9 & pT3 & 0 & $4+3$ & $\mathrm{G} 2$ & 0 & 0 \\
\hline 0.11 & 71 & 60 & 0 & 11 & 57 & 8.7 & pT3 & 0 & $4+3$ & $\mathrm{G} 2$ & 85 & 75 \\
\hline 0.12 & 74 & 0 & 0 & 12 & 72 & 9.5 & pT2b & 0 & $2+2$ & G1 & 0 & 0 \\
\hline 0.13 & 79 & 0 & 0 & & & & & & & & & \\
\hline 0.14 & 72 & 0 & 0 & & & & & & & & & \\
\hline 0.15 & 78 & 45 & 0 & & & & & & & & & \\
\hline
\end{tabular}

ID, identification; PSA, prostate specific antigen; pT, tumor stage; N, lymphonodes; NA, lymphonodes not excissed; G, grading. 
tissues suggests that the expression of SPANX genes in prostate carcinomas correlates with their expression in normal cells from which the tumor originates: a finding similar to what previously described in seminomas, ${ }^{5}$ where nonetheless the nuclear positivity involves approximately $100 \%$ of the cells. Since our antibody was generated by immunizing mice with a synthetic peptide, which sequence is shared by almost all known SPANX proteins, ${ }^{4}$ we cannot differentiate SPANX-B form SPANXA-like subfamilies. Although this is a limiting aspect, we believe that, given the high homology among SPANX gene family members, it would be difficult to assess the specificity of any antibody for a SPANX subfamily or for a single member, especially for immunohistochemical purposes. In conclusion, the present findings showed that SPANX expression is physiological in $40 \%$ of normal individuals, at least in the Sicilian sample examined in this study. This might relate to predisposing haplotypes of SPANX locus. ${ }^{3}$ The similar incidence of SPANX-positive cells in normal and neoplastic tissues, although suggestive, is not sufficient to establish a causative relationship between SPANX expression and prostate cancer tissues, and deserves more detailed studies in additional patients.

\section{References}

1. Kolonel LN, Altshuler D, Henderson BE. The multiethnic cohort study: exploring genes, lifestyle and cancer risk. Nat Rev Cancer 2004;4:519-27.

2. Xu J, Meyers D, Freije D, Isaacs S, Wiley K, Nusskern D, et al. Evidence for a prostate cancer susceptibility locus on the $\mathrm{X}$ chro- mosome. Nat Genet 1998;20:175-79.

3. Baffoe-Bonnie AB, Smith JR, Stephan DA, Schleutker J, Carpten JD, Kainu T, et al. A major locus for hereditary prostate cancer in Finland: localization by linkage disequilibrium of a haplotype in the HPCX region. Hum Genet 2005;117:307-16.

4. Salemi M, Calogero AE, Di Benedetto D, Cosentino A, Barone N, Rappezzo G, et al. Expression of SPANX proteins in humanejaculated spermatozoa and sperm precursors. Int J Androl 2004;27:134-9.

5. Salemi M, Calogero AE, Castiglione R, Tricoli D, Asero P, Rosa R, et al. Expression of SpanX proteins in normal testes and in testicular germ cell tumours. Int $\mathbf{J}$ Androl 2006;29:368-73.

6. Stephan DA, Howell GR, Teslovich TM, Coffey AJ, Smith L, Bailey-Wilson JE, et al. Physical and transcript map of the hereditary prostate cancer region at $\mathrm{xq} 27$. Genomics 2002;79:41-50.

7. Kouprina N, Pavlicek A, Noskov VN, Solomon G, Otstot J, Isaacs $\mathrm{W}$, et al. Dynamic structure of the SPANX gene cluster mapped to the prostate cancer susceptibility locus HPCX at Xq27. Genome Res 2005;15:1477-86.

8. Bailey JA, Gu Z, Clark RA, Reinert K, Samonte RV, Schwartz S, et al. Recent segmental duplications in the human genome. Science 2002;297:1003-7.

9. Kouprina N, Noskov VN, Solomon G, Otstot $\mathrm{J}$, Isaacs $\mathrm{W}, \mathrm{Xu} \mathrm{J}$, et al. Mutational analysis of SPANX genes in families with X-linked prostate cancer. Prostate 2007;67:820-28.

10. Westbrook VA, Diekman AB, Klotz KL, Khole VV, von Kap-Herr C, Golden WL, et al. Spermatid-specific expression of the novel X-linked gene product SPAN-X localized to the nucleus of human spermatozoa.
Biol Reprod 2000;63:469-81.

11. Salemi M, Calogero AE, Bosco P, Castiglione R, La Vignera S, Borgione E, et al. Expression of SpanX mRNA in testicular germ cell tumors. Hum Cell 2006;19:8790.

12. Zendman AJ, Zschocke J, van Kraats AA, de Wit NJ, Kurpisz M, Weidle UH, et al. The human SPANX multigene family: genomic organization, alignment and expression in male germ cells and tumor cell lines. Gene 2003;309:125-33.

13. Almanzar G, Olkhanud PB, Bodogai M, Dell'Agnola C, Baatar D, Hewitt SM, et al. Sperm-derived SPANX-B is a clinically relevant tumor antigen that is expressed in human tumors and readily recognized by human CD4+ and CD8+ T cells. Clin Cancer Res 2009;15:1954-63.

14. Wang Z, Zhang Y, Liu H, Salati E, ChirivaInternati M, Lim SH. Gene expression and immunologic consequence of SPAN-Xb in myeloma and other hematologic malignancies. Blood 2003;101:955-60.

15. Salemi M, Bosco $\mathrm{P}$, Calì $\mathrm{F}$, Calogero $\mathrm{AE}$, Soma PF, Galia A, et al. SPANX-B and SPANX-C (Xq27 region)gene dosage analysis in Sicilian patients with melanoma. Melanoma Res 2008;18:295-9.

16. Salemi M, Calogero AE, Vicari E, Migliore E, Zaccarello G, Cosentino A, et al. A high percentage of skin melanoma cells expresses SPANX proteins. Am J Dermatopathol 2009;31:182-6.

17. Westbrook VA, Schoppee PD, Diekman AB, Klotz KL, Allietta M, Hogan KT, et al. Genomic organization, incidence, and localization of the SPAN-X family of cancer-testis antigens in melanoma tumors and cell lines. Clin Cancer Res 2004;10: 101-12. 